Money and Finance in Central Europe during the Later Middle Ages 
Series Editors: Martin Allen, D'Maris Coffman, Tony K. Moore and Sophus Reinert

The study of the history of financial institutions, markets, instruments and concepts is vital if we are to understand the role played by finance today. At the same time, the methodologies developed by finance academics can provide a new perspective for historical studies. Palgrave Studies in the History of Finance is a multi-disciplinary effort to emphasise the role played by finance in the past, and what lessons historical experiences have for us. It presents original research, in both authored monographs and edited collections, from historians, finance academics and economists, as well as financial practitioners.

Titles include:

Alisdair Dobie

ACCOUNTING AT DURHAM CATHEDRAL PRIORY

Ali Coskun Tunçer

SOVEREIGN DEBT AND INTERNATIONAL FINANCIAL CONTROL

The Middle East and the Balkans, 1868-1914

Kiyoshi Hirowatari

BRITAIN AND EUROPEAN MONETARY COOPERATION, 1964-1979

Adrian Williamson

CONSERVATIVE ECONOMIC POLICYMAKING AND THE BIRTH OF

THATCHERISM, 1964-1979

Rafael Torres Sanchez

CONSTRUCTING A FISCAL MILITARY STATE IN EIGHTEENTH

CENTURY SPAIN

Stuart J. Barton

POLICY SIGNALS AND MARKET RESPONSES

Ali Kabiri

THE GREAT CRASH OF 1929

Martin Allen, D'Maris Coffman

MONEY, PRICES AND WAGES

Guy Rowlands

DANGEROUS AND DISHONEST MEN

The International Bankers of Louis XIV's France

Duncan Needham

UK MONETARY POLICY FROM DEVALUATION TO THATCHER, 1967-1982

D'Maris Coffman

EXCISE TAXATION AND THE ORIGINS OF PUBLIC DEBT

\footnotetext{
Palgrave Studies in the History of Finance series

Series Standing Order ISBN: 978-1-137-34224-9

(outside North America only)

You can receive future titles in this series as they are published by placing a standing order. Please contact your bookseller or, in case of difficulty, write to us at the address below with your name and address, the title of the series and the ISBN quoted above.

Customer Services Department, Macmillan Distribution Ltd, Houndmills, Basingstoke, Hampshire RG21 6XS, England
} 


\section{Money and Finance in Central Europe during the Later Middle Ages}

Edited by

Roman Zaoral

Faculty of Humanities, Charles University, Czech Republic 


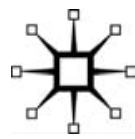

Selection, introduction and editorial matter @ Roman Zaoral 2016 Chapters (C) Contributors 2016

Softcover reprint of the hardcover 1st edition 2016 978-1-137-46022-6

All rights reserved. No reproduction, copy or transmission of this publication may be made without written permission.

No portion of this publication may be reproduced, copied or transmitted save with written permission or in accordance with the provisions of the Copyright, Designs and Patents Act 1988, or under the terms of any licence permitting limited copying issued by the Copyright Licensing Agency, Saffron House, 6-10 Kirby Street, London EC1N 8TS.

Any person who does any unauthorized act in relation to this publication may be liable to criminal prosecution and civil claims for damages.

The authors have asserted their rights to be identified as the authors of this work in accordance with the Copyright, Designs and Patents Act 1988.

First published 2016 by

PALGRAVE MACMILLAN

Palgrave Macmillan in the UK is an imprint of Macmillan Publishers Limited, registered in England, company number 785998, of Houndmills, Basingstoke, Hampshire RG21 6XS.

Palgrave Macmillan in the US is a division of St Martin's Press LLC, 175 Fifth Avenue, New York, NY 10010.

Palgrave Macmillan is the global academic imprint of the above companies and has companies and representatives throughout the world.

Palgrave ${ }^{\circledR}$ and Macmillan ${ }^{\circledR}$ are registered trademarks in the United States, the United Kingdom, Europe and other countries.

\section{ISBN 978-1-349-56703-4ＩSBN 978-1-137-46023-3 (eBook) \\ DOI $10.1057 / 9781137460233$}

This book is printed on paper suitable for recycling and made from fully managed and sustained forest sources. Logging, pulping and manufacturing processes are expected to conform to the environmental regulations of the country of origin.

A catalogue record for this book is available from the British Library.

Library of Congress Cataloging-in-Publication Data

Money and finance in Central Europe during the later middle ages / edited by Roman Zaoral.

pages $\mathrm{cm}$. - (Palgrave studies in the history of finance)

1. Money - Europe - History. 2. Finance - Europe - History. 3. Europe History. 4. Economic history. I. Zaoral, Roman, editor.

HG923.M66 2015

332.0943'0902—dc23 
In memory of my parents 
This page intentionally left blank 


\section{Contents}

List of Figures ix

List of Tables $\quad \mathrm{x}$

Preface - xi

Acknowledgements $\quad$ XV

Notes on Contributors $\quad$ xvi

Introduction: Medieval Finance in Central European Historiography 1 Roman Zaoral

\section{Part I Money and Minting}

1 A New Perspective on the Imperial Coinage Hendrik Mäkeler

2 The Reception of Imperial Monetary Reforms in 16th-Century Northern Germany

Michael North

3 The Kremnica Town Book of Accounts: The Economy of a Mining and Mint Town in the Kingdom of Hungary Martin Štefánik

\section{Part II Medieval Court Funding}

4 Financiers to the Blind King: Funding the Court of John the Blind (1310-1346)

Zdeněk Žalud

5 The Financial Dimension of the Pledge Policy of King Sigismund of Luxembourg in Bohemia (1419-1437)

Stanislav Bárta

6 The Pledge Policy of King Sigismund of Luxembourg in Hungary (1387-1437)

János Incze 
7 The Economic Background to and the Financial Politics of Queen Barbara of Cilli in Hungary (1406-1438)

Daniela Dvořáková

8 The Courtly Accounts of Prince Sigismund Jagiello (Late 15th to Early 16th Centuries) and Their Historical Context Petr Kozák

\section{Part III Trade and Towns}

9 Accounting Records of the Town Offices in Bohemia and Moravia: Methodology and Application

Pavla Slavíčková and Zdeněk Puchinger

10 Remnants and Traces: In Search of Wrocław's Accounting Books (Late 14th to Early 16th Centuries)

Grzegorz Myśliwski

11 Financial Obligations of the City of Gdańsk to King Casimir IV Jagiellon and His Successors in the Light of the 1468-1516 Ledger Book

Beata Możejko

12 Old Interpretations and New Approaches: The 1457-1458

Thirtieth Customs Registers of Bratislava

Balázs Nagy

\section{Part IV Church and Money}

13 Financing a Legation: Papal Legates and Money in the Later Middle Ages Antonín Kalous

14 St Vitus Building Accounts (1372-1378): The Economic Aspects of Building the Cathedral Marek Suchý

15 'De mandato dominorum divisorum...': Finances in the Life of Prague's Metropolitan Chapter Martina Maříková 


\section{List of Figures}

2.1 The Lower (grey) and Upper (black) Saxon Imperial Circles 34

2.2 Communication structures of the Lower Saxon Imperial Circle for 'Monetary Issues', 1579-1581

14.1 Weekly activity of setters, masons, carpenters and day labourers measured by their numbers at the building site or weekly expenses on their salaries in 1376

14.2 Weekly expenses for day labourers and their numbers (when recorded) at the building site in 1373

14.3 Weekly expenses for carpenters and their numbers (when recorded) at the building site in 1377

14.4 Weekly activity of carters and stonecutters measured by their numbers at the building site and amount of wagons or stone pieces delivered in 1376

14.5 Total expenses for different building activities in $1373 \quad 237$

14.6 Total expenses for different building activities in $1375 \quad 237$

14.7 Total expenses for different building activities in $1376 \quad 238$

14.8 Total expenses for different building activities in $1377 \quad 238$

14.9 Expenses for binding material in 1376 


\section{List of Tables}

3.1 Income in gold florins 48

3.2 Income in accounting florins 48

3.3 Expenditure in accounting florins 51

3.4 Expenditure in gold florins 51

3.5 Contributions of the town and wealthiest burghers $\quad 52$

3.6 Loans provided by the town 52

4.1 Creditors and debts 61

8.1 Types of currency 141

12.1 Balance of foreign trade 194

12.2 Distribution of imported goods 194

12.3 Distribution of exported goods 195

15.1 Time span of accounting registers 248

15.2 Content of the registers 249

15.3 Regular income of the common treasury 249

15.4 Principal expenditures of the common treasury 251

15.5 Evidentiary value of accounting registers 258 


\section{Preface}

Money is a topic of enduring importance. Nevertheless, the financial history of Central Europe during the Middle Ages has lain outside the mainstream of scholarly interest for a long time. The aim of this volume is to fill this gap by publishing contributions by Central European historians that were presented at the international conference 'Financial Aspects of the Medieval Economy', held at Charles University in Prague on 17-19 October 2013.

All of the chapters are based on primary sources. They focus on both the broader context of monetary and fiscal policy and the analysis of different types of accounting sources. The authors pay attention to technical questions relating to the ways in which accounting entries have been recorded; how taxes, loans, debts, credit and account books themselves have been organized. Further, they consider what light these accounts can shed on everyday life, including on the value of things and their exchange, prosopographical possibilities and what they reveal about habitual practices. The contributions draw on late medieval sources found in various archives in Germany, Austria, Czech Republic, Slovakia, Poland and Hungary. They allow us to investigate the institutions in which they originated, and to reconstruct the budget of a given originator or the supply of money in circulation. Nevertheless, working with a large number and variety of documents gives rise to considerable methodical problems. Some of the following chapters therefore also analyse the internal structure and genesis of accounts to demonstrate how such sources, which seem at first sight to be standardized and homogeneous, are in fact, much more diverse and problematic on closer examination.

The analysis of late medieval financial sources from Central Europe can help us to explain aspects of the economy and society at that time, as well as everyday life in the broadest sense of the word. It also contributes to debates on the structure of such records and the methods used by their creators. At the same time it can introduce these questions and materials to an English speaking community of historians and thus serve as a basis for comparison with financial conditions in Western Europe. This will allow a better understanding of how Central Europe can properly be incorporated into European history. 
The volume is divided into four thematic parts preceded by a treatise on Central European historiography concerning medieval finance.

The first thematic part is concerned with money and minting. Hendrik Mäkeler highlights areas that were of importance for the imperial coinage of the 14th century, including a projected monetary policy that would have united the west and east European currency systems. At the same time he explains how innovations in monetary theory and in finance originated in and around the major mints in Central Europe. Michael North deals with 16th-century monetary reforms in the Holy Roman Empire. These have been traditionally regarded as a failure by monetary historians and numismatists, but his chapter clarifies the communication processes between the Imperial Estates (princes and cities) in Northern Germany and the reformers working on behalf of the emperor. In particular, the differing interests between princes and cities and their strategies to gain support on the Imperial Diet (Reichstag) is examined. Martin Štefánik then focuses on the economic situation of Kremnica (Kremnitz/Körmöcbánya), the main mining and minting town in the Kingdom of Hungary during the reign of Sigismund of Luxemburg (1387-1437). His analysis of the Kremnica town book of accounts from 1423 to 1424 makes it possible to explore the structure of regular tax incomes, terms of tax collections, financial reserves and various expenses of this mining town. The book of accounts also contains information about the changing values of silver and gold coins, an issue which was of great importance for currency conditions in the whole Kingdom of Hungary.

The second part consists of five chapters related to medieval court funding. Zdeněk Žalud examines the role of credit in the territorial policy of John the Blind, King of Bohemia (1313-1346). This extraordinary source of income allowed the king not just to expand the territory of the county of Luxembourg, but also to acquire Upper Lusatia and Silesia. The chapter also deals with the activities and personal careers of four main creditors of the king: Peter I of Rosenberg, Arnold of Arlon, Frenzlin Jacobi of Prague and Gisco (Gisilbert) of Reste. King Sigismund of Luxembourg frequently resorted to pledging royal properties and this policy is the subject of two chapters: Stanislav Bárta traces the situation in Bohemia and János Incze in Hungary. Their studies are based on the analysis of sums pledged in relation to the annual issues of the pledged property as well as to other duties that the recipients were expected to fulfil. They also pay close attention to the legal phrasing and political rhetoric of pledge deeds, the size of the financial sums paid by pledgees as well as their personal stories. The economic background and financial 
policy of Queen Barbara of Cilli in Hungary (1406-1438) is analysed by Daniela Dvořáková. With reference to charter evidence, she deals with the way the queen's extensive possessions were administered, as well as her incomes and expenses, including her debts and shopping in foreign markets. By analysing two court accounts, Petr Kozák explores the economic background to the travels of Prince Sigismund Jagiellon (late 15th to early 16th centuries). He investigates how finances, services and information were distributed, as well as sheds light on Sigismund's remarkable mobility.

The third part tackles trade and towns and includes four studies; Pavla Slavičková and Zdeněk Puchinger seek to establish a methodology for the study of early accounting history. They study the techniques and operating procedures found in the accounting records used in the town offices of Bohemia and Moravia before 1750. Their proposed methodology is based on the examination of accounting institutes (balance sheet, final accounts) and accounting record keeping (particularly principles of continuity, balance sheet and completeness of records) from the moment of their origin through their subsequent development. At the same time, the authors present the first results from their analysis of the accounting books of the City of Olomouc in comparison with sources from other town offices in Bohemia and Moravia. Financial conditions in late medieval Breslau (Wrocław), the capital of Silesia, are the subject of the study by Grzegorz Myśliwski. This chapter focuses on fragments from lost accounting books, based on the assessment and interpretation of some direct references to them as well as on their indirect reflections in other sources. The author tries to answer the question of how much they were used by Breslau merchants. He also considers wider trends in the development of the economic administration in the city, including the use of double-entry bookkeeping. Another important trade city of medieval Central Europe is at the centre of Beata Możejko's exploration of the role that the rents owed by the city played in the financial relationship between Danzig (Gdańsk) and Casimir IV, King of Poland (1440-1492). Using this connection, she also examines the way in which Danzig's financial obligations were recorded and realized. The 1457-1458 thirtieth customs registers of Pressburg (Pozsony/Bratislava) represent one of the most studied and frequently debated sources for the economic history of Hungary during the Middle Ages. Balázs Nagy seeks to re-interpret this source from the viewpoint of an adverse balance of Hungarian trade.

The fourth part is focused on the role of money in the church. Antonín Kalous discusses the various ways by which the legations of papal legates 
throughout the Middle Ages were financed. The chapter highlights the different sources of payments for cardinal legates and other types of legates and nuncios, varying from procuratio canonica to individual benefices and the central income of the papal chamber, and how these changed from the 11th to the 16th centuries. Although its findings are wide-ranging, its main attention is on legations in Central Europe. Marek Suchý deals with the economic aspects of the construction of St Vitus cathedral in Prague. This research is based on a thorough analysis of weekly building accounts dated back to 1372-1378. The chapter grapples with methodological questions such as what has been recorded in the accounts (and, equally importantly, what has been not recorded) and in what manner the entry was made. A comprehensive interpretation of the accounts, in combination with other written, archaeological and iconographical sources, allows Suchý to reconstruct the course of the building work week-by-week. The accounts also shed light on wider economic questions. They are an invaluable source of information on the price of building materials and the living standards of the craftsmen working on the building site. In this way the author tries to quantify the total expenses for various building activities in particular years. The final contribution analyses four accounting registers and two fragments of the Prague Metropolitan Chapter from 1358 to 1418, which have been quite unknown until now. The broad spectrum of data contained in this source allows Martina Maříková to study a variety of different aspects of everyday life in the church milieu. The chapter poses important questions concerning accounting methods, the material conditions of residential canons and the chapter economy shortly before the Hussite Revolution. 


\section{Acknowledgements}

I would like to pay tribute to a number of institutions and people who have helped to make this volume possible. It is the output of the international conference which would not have come into being without the generous financial support of my home Faculty of Humanities at Charles University in Prague and of the Centre for Medieval Studies, joint workplace of Charles University and the Academy of Sciences of the Czech Republic, which provided lecture hall with all needed facilities. I am also immensely grateful to D'Maris Coffman, Tony K. Moore and Martin Allen for enforcement of their intent to publish conference papers within the Palgrave Studies in the History of Finance series and to the editorial team of Palgrave Macmillan, who showed the highest professional skill and flexibility in handling the project from start to finish. I would also like to offer heartfelt thanks to Tony K. Moore and Michael Goddard for language corrections, to František Kalenda for preparing the index as well as to all contributors for their valuable feedback on the ideas and evidence presented herein. My thanks are also due to the Gallery of the Central Bohemian Region for permission to reprint the late medieval Kutná Hora illumination on the cover of this volume. Last but not least, I would like to express my deepest gratitude to my wife and my sister for their continuous support. 


\section{Notes on Contributors}

Stanislav Bárta is an assistant professor and vice-head in the Department of Auxiliary Historical Sciences and Archive Studies at the Faculty of Arts, Masaryk University, Brno, Czech Republic. Since 2011 he has worked as a junior research fellow at the Regesta Imperii, Branch Office Brno, on the project The Charters of Emperor Sigismund.

Daniela Dvořáková is a senior research fellow at the Institute of History, Slovak Academy of Sciences, Bratislava, Slovakia. Her research relates to history of nobility in Upper Hungary (today's Slovakia) during the later Middle Ages. She is the author of several monographs, recently on Barbara of Cilli, Queen of Hungary, Čierna královná Barbora Celjská (2013).

János Incze is a PhD student in the Department of Medieval Studies at Central European University, Budapest, Hungary. His thesis focuses on King Sigismund's pledging policy and its role in the royal finances of late medieval Hungary.

Antonín Kalous is Reader in Medieval History at the Faculty of Arts, Palacký University, Olomouc, Czech Republic. His field of interest is late medieval ecclesiastical, cultural and political history with special attention to Central Europe and Italy. He is the author of Matyáš Korvín uherskýa český král (2009) and a monograph on papal legates and nuncios in Central Europe, Plenitudo potestatis in partibus? (2010).

Petr Kozák is an archivist in the Provincial Archives in Opava, Czech Republic, a research fellow in the Silesian Museum and external lecturer at Silesian University in Opava. He is the author of a critical edition of the courtly accounts of Prince Sigismund Jagiellon, Účty dvora prince Zikmunda Jagellonského, (1493) 1500-1507 (2014).

Hendrik Mäkeler is the keeper of the Uppsala University Coin Cabinet, Sweden. His research interests include numismatics and monetary history, the history of economic thought, business and banking history. His PhD dissertation on the Imperial coinage in the later Middle Ages was published by Franz Steiner Verlag (2010).

Martina Maříková is an archivist in the Prague City Archives, Czech Republic. In 2014 she defended her PhD dissertation on the 'communal 
treasury' of the Prague Cathedral Chapter at the turn of the 15th century at Charles University. Her research interests also include watermills and water management in the Middle Ages and the history of Prague Mercantile Exchange.

Beata Możejko is a professor at the Institute of History, University of Gdańsk, Poland. Her main area of research is the history of late medieval City of Gdańsk and of the Hanseatic League. In her recent monograph, she pays attention to Peter von Danzig in context with the story of a great caravel in 1462-1475 (2011).

Grzegorz Myśliwski is an associate professor at the Institute of History, University of Warsaw, Poland. He focuses on the study of medieval mentality and economy with special attention to long-distance trade. He is the author of Wroctaw in the Economic Space of Europe between the Thirteenth and the Fifteenth Century: Core or Periphery? (2009).

Balázs Nagy is Associate Professor of Medieval History at Eötvös Loránd University and in the Department of Medieval Studies, Central European University, Budapest, Hungary. His main field of interest is medieval economic and urban history of Central Europe. He is the co-editor of the Latin-English edition of the autobiography of Emperor Charles IV (2001) and of the volume Segregation - Integration - Assimilation: Religious and Ethnic Groups in the Medieval Towns of Central and Eastern Europe (2009).

Michael North is Professor and Chair of Modern History at the University of Greifswald, Germany, Honorary Doctor of the University of Tartu, Estonia, and Director of the International Graduate Programme 'Baltic Borderlands'. His recent books include The Expansion of Europe, 1250-1500 (2012) and The Baltic: A History (2015).

Zdeněk Puchinger is an assistant professor in the Department of Applied Economics at Palacký University, Olomouc, Czech Republic. His research focuses on accounting and banking in general. He is the co-author of the monograph Malé dějiny účetnictví [Short History of Accounting] (2014).

Pavla Slavíčková is an assistant professor in the Department of Applied Economics at Palacký University, Olomouc, Czech Republic. Her research interest focuses on economic theories and economic and legal history, particularly the history of accounting. She is the author of a monograph on the legal protection of children Právní ochrana dětí v období prvních kodifikací (2012) and the co-author of Malé dějiny účetnictví [Short History of Accounting]. 
Marek Suchý is the keeper of the Metropolitan Chapter Library and Archive, The Archives of Prague Castle, Czech Republic. Medieval building and Anglo-Bohemian relations are his main areas of research. His monograph Solutio Hebdomadaria Pro Structura Templi Pragensis deals with St Vitus building accounts dating back to 1372-1378 (2003).

Martin Štefánik is the head of Department of Medieval History at the Institute of History, Slovak Academy of Sciences, Bratislava, Slovakia. His research focuses on medieval towns, mining and long-distance trade. He is the author of a monograph relating to the trade war of King Sigismund against Venice, Obchodná vojna krála Žigmunda proti Benátkam (2004) and co-author of a lexicon of medieval towns in Slovakia, Lexikon stredovekých miest na Slovensku (2010).

Roman Zaoral is Senior Lecturer in Medieval History in the Faculty of Humanities, at Charles University, Prague, Czech Republic. His research in the field of monetary and financial history concerns medieval trade and cultural exchange between Venice and Bohemia, papal collections management in Central Europe, taxation of late medieval towns, ready money of pilgrims and circulation of gold in Italy. He also participated in the international project regarding the Fuchsenhof hoard Der Schatzfund von Fuchsenhof (2004).

Zdeněk Žalud is Lecturer in Helping Professions in the Department of Philosophy and Ethics at the University of South Bohemia in České Budejjovice, Czech Republic. He specializes in the era of King John the Blind, medieval nobility and court culture. He is working on the annotated critical edition of the Chronicon Aulae Regiae. 